\title{
Public markets, private orderings and corporate governance
}

\author{
Ugo Pagano* \\ Università di Siena, Dipartimento di Economia Politica, Piazza S. Francesco 7, 53100 Siena, Italy
}

accepted 6 September 2000

\begin{abstract}
In the New Property Rights approach the degree of incompleteness of markets is taken independently of the cost of the public ordering and of their efficiency relatively to private orderings. In this approach "public markets," similarly to a Swiss cheese, are either assumed to be nonexistent empty holes (because of infinite third party verification costs) or assumed to be smooth and efficient (because of zero third party verification costs). When we allow for positive but not infinite third party verification costs we are necessarily pushed back to the insights of Commons, Coase, Fuller and Williamson. The degree of (in)completeness of public markets becomes an endogenous economic problem and managers can be seen as agents that make "second order" specific investments to run specific relations that cannot be efficiently handled by public markets. Managers and the public authorities build respectively private and public "legal equilibria" that set the working rules within which transactions can take place. Private and public legal equilibria are not only substitutes but also complements. This complementarity is an important source of the path dependency that characterizes the development of different legal systems. The framework is applied to GM's acquisition of Fisher Body. We suggest that, contrary to the claims of the New property Rights approach, the advantages of the acquisition were not due to the superior incentives of the new private owners but should be rather related to the replacement of public markets by the new private ordering set up by Alfred Sloan. (c) 2000 Elsevier Science Inc. All rights reserved.
\end{abstract}

JEL classification: K00; K10; L22; P51; D23

* Tel.: +577-232614; fax: +577-232661.

E-mail address: pagano@unisi.it (U. Pagano). 


\section{Introduction}

In a famous passage, quoted by Coase in his 1937 article on Nature of the Firm (p. 35), Denis Robertson (1928) observed how in the market economy we find "islands of conscious power in this ocean of unconscious cooperation like lumps of butter coagulating in a pail of buttermilk." The main question asked by Coase -"Why are there these islands of conscious power?" was obviously influenced by this parallel with the world of diary products.

In spite of its self-declared Coasian spirit, after many years, the New Property Rights approach has managed to describe the problem in a way that obscures the comparative institutional approach introduced by Coase. The memory of the butter and the buttermilk has faded away together with the question asked by Coase. Its place has been taken by some sort of Swiss cheese where holes of incomplete contracts are open in a desert of perfectly working and costless markets.

The starting point of this paper is the Coasian comparative analysis of markets and firms. In this perspective the incompleteness of market contracts cannot be exogenously taken as the holes of a Swiss cheese. It is related to the degree of development of the legal and judiciary system that absorbs relevant scarce resources whose allocation has been traditionally the most important economic problem. Moreover, the public ordering is not the only way by which the goal to subject human activity to the governance of rules is carried out. Private orderings, including firms, should be considered as complements and/or substitutes to the legal and judiciary system which help the smooth working of public markets. In this respect the Coasian contribution can be usefully integrated with the work of Lon Fuller who saw the firm as one of the ways by which the public ordering was decentralized in the actual working of modern economies. This is done in the following section of this paper.

The third section of the paper shows how the Fuller-Coase analysis can be integrated by referring to Commons' elaboration of the fundamental jural relations considered by Hohfeld. The standard transactions, considered by economic theory, assume implicitly a "legal equilibrium" where the rights, duties, the liberties and the exposures of each agent are compatible with those of the other agents. Commons contribution can be used to show that this "legal equilibrium" cannot be taken for granted and that the standard transactions considered by orthodox economic theory require authoritative transactions with public officials that contribute to the "convergence" to a legal equilibrium. More, in general, "private orderings" are essential to the working of this equilibrating process and the type of legal equilibrium posited by Hohfeld's classification would be impossible if the many agents, belonging to the private sphere of the economy, would not share the burden of eliminating the legal disequilibrium. Private property itself can be interpreted as an elementary private ordering whose real advantages can only be seen in a world of costly public markets.

The fourth section contrasts the New Property Rights emphasis on the efficient allocation of the private property of the means of production with the role of more complex private orderings. It is argued that the "Swiss cheese assumption" typical of the New Property Right approach is tantamount to assuming that third party verification is either costless or infinitely costly. This assumption inhibits the development of any theory of the degree of completeness that should be achieved by the public ordering by the means of public investments. Moreover, it does not allow the understanding of the investments, carried out by private agents, 
that increase the capacity to device working rules for other agents and to verify their behavior. In other words, in the New Property Right approach, the firm cannot be explained as a private ordering where some agents make "second order" specific investments to manage some specific relations (or, in other words, develop specific organizational capital). By contrast, the institutions of corporate governance may be thought of as the results of the investments that agents make to overcome the problems of contract incompleteness. Public courts have an obvious advantage for investments requiring mostly general purpose investments related to the application of standard contracts while market intermediaries have an advantage when verification of more specific relations requires in turn also more specific investments. However, when the relations to be verified are very specific, it may be advantageous to set up and run a "private ordering" that is handled by agents who have, in turn, made very specific "second order" investments in the "specific" relations that have to be managed. Or, in other words, in this case it may be advantageous to internalize the transactions within an institution like a firm.

The acquisition of Fisher Body by GM has been considered by the New Property Right approach as a classic example to illustrate the incentive effects of ownership. In the fifth section we argue that the advantages of the acquisition cannot be easily attributed to the virtues of a better allocation of the private property of physical capital. By contrast, it can be related to the possibility of a successful integration of Fisher Body (and of the Fisher brothers) in the new form of private ordering that had been created by Alfred Sloan at GM. The "second order" specific investments of Sloan and other managers in the setting up and the running of the new private order can explain the advantages of the integration.

Finally, the concluding section argues that the relation of complementarities and substitution between private and public orderings imply that in each country the "efficiency" of a model of corporate governance cannot be seen independently of its history. One of the few general conclusions seems to be that more markets may mean more public investments in the public ordering of the economy.

\section{Centralization of market transactions and decentralization of the public ordering}

Coase's 1960 article on the nature of the social cost has become famous for the so-called "Coase theorem" on externalities for a world of zero transaction costs. However, the most valuable part of the article is perhaps where he restates the consequences of the assumption of positive transaction costs .

While in a world of zero transaction costs, markets can deal with all sorts of economic interactions (including the "externalities" of the Pigouvian tradition), in a world of positive transaction costs (where all forms of economic organizations are costly) an institutional mix is likely to characterize real life economies.

Like in his famous 1937 article on the nature of the firm, also in the second part of the 1960 article the firm reappears as possible substitute for the use of the market. "It is clear that an alternative form of economic organization which could achieve the same result at less cost that would be incurred by using the market would enable the value of production to be raised. 
As I explained many years ago the firm represents such an alternative to organizing market transactions" (1960, p. 115). Coase emphasizes how "unified" private property of a factor of production allows the rearrangement of production to take place without bargains among the owners of the factors of production. He considers how a "landowner who has control of a large tract of land may devote his land to various uses, taking into account the effect that the interrelations of the various activities will have on the net return of land, thus rendering unnecessary bargains between those undertaking the various activities" (Coase 1960 p. 116). Thus, the firm is an organization, alternative to both the market and the state, that allows the "internalization" of (former) externalities. In a world of positive transaction costs unified private property can save on the cost of using the market mechanism: "the firm would acquire the legal rights of all the parties, and the rearrangement of activities would not follow on rearrangement of rights by contract but as a result of an administrative decision as to how the rights should be used" (Coase 1960 p. 116).

In his 1937 article Coase points out that the relevant comparison is that between the administrative costs of organizing a transaction through a firm and the costs of market transactions. According to him the former are likely to be lower than the latter whenever the "contracts are peculiarly difficult to draw up and an attempt to describe what the parties have agreed to do or not to do ..... would necessitate a lengthy and highly involved document. ...." "But the firm-Coase observes - is not the only possible answer to this problem." According to Coase "an alternative solution is direct governmental regulation" (Coase 1960 p. 116). Unlike a firm, government intervention is not subject to competition. Moreover, unlike a firm, the government can conscript and size property and it has at its disposal the police and other law enforcement agencies. However, Coase maintains that the government "is, in a sense, a superfirm (but of a special kind) since it is able to influence the use of factors of productions by administrative decisions" (p. 116). In comparison to both firms and markets is some cases "the government has powers which might enable it to get things done at a lower cost that could a private organization..." However, even ignoring governmental mistakes "the governmental administrative machine is not itself costless" and it "can, in fact, on occasion be extremely costly."

Thus, the first part of his 1960 article (where the conditions of so called "Coase theorem" would be satisfied) is only instrumental to move towards a world where no organizational "free lunch" is possible and all types of transactions are costly. The problem is "one of choosing the appropriate social arrangement" in a world where "all solutions have costs." Moreover, given the nature of the problem, the existence of "externalities" does not involve that the costs of setting up a "social arrangement," that deals with them, will always outweigh its benefits. Thus, each one of the institutions like market contracts, firms, judiciary and the state covers only a part of individual interactions and, moreover, the overall mix of these "social arrangements" is necessarily incomplete.

Coase's journey starts from the criticism of the world of costless decentralized markets of standard economic theory and moves towards the understanding of the real life complex world characterized by diverse and incomplete institutional orderings. One may gain some further insight in Coase's journey by considering the work of Lon Fuller. Fuller's journey departs from the criticism of a world that may superficially appear located at the opposite pole: a world where a complete public ordering exists. Fuller shows the shortcomings of the 
traditional view of law that takes for granted the existence of a complete public ordering. We will, however, see that his criticism of the assumption of a zero-cost public ordering can be somehow related to the Coasian criticism of the assumption of zero market transaction costs.

According to Fuller (1958) the generality and reciprocity of commands defines the minimum moral contents for a legal system to be distinguished from a simple system of arbitrary commands. The basic object of law-making is to subject human conduct to the governance of rules. Law-making is a purposive activity which can fail in greater or small degree. Like any other purposive activity, law making requires attention to certain practical precepts that are related to the ultimate purpose of the activity. According to Fuller (1969, p. 39), if the object of law-making is to be achieved, one must try to follow eight of such precepts:

(i) there must be rules

(ii) they must be prospective non retrospective

(iii) the rules must be published

(iv) the rules must be intelligible

(v) the rules must not be contradictory

(vi) compliance with the rules must be possible

(vii) the rules must not be constantly changing

(viii) there must be congruence between the rules as declared and as applied by officials.

According to Fuller these eight principles represent eight ways in which the enterprise of law-making can go astray. They point to eight minimum conditions for the existence of anything that we would regard as law or a legal system. For example, a system where all the rules are kept secret, or where all the rules where retrospective, would not normally thought of as a legal system. Complete failure to comply with any one of the eight principles results in something that is not law at all. On the other hand, complete success is impossible to achieve for real-life human societies. When human societies aspire to subject human behavior to the governance of rules, "the principle of marginal utility plays an increasing role in our decisions." In this case "something like and economic calculation may become necessary when a conflict arises between the internal and the external morality of law" (Fuller 1969 p. 44). Costly resources have to be expended to achieve the objectives of law-making: given the limitations of our resources and capacities, the achievement of one objective implies the sacrifice of other objectives. According to Fuller there are "trade-off" not only between law and other objectives but also among the different objectives of law.

A conflict between the internal and external morality of law may easily arise. On the one hand the "internal morality of law" requires that the laws do not change too often otherwise its rules cannot satisfactorily guide human behavior (principle vii). On the other hand, "it is obvious that changes in circumstances, or changes in men's consciences, may demand changes in the substantive aims of law, and sometimes disturbingly frequent changes" (Fuller 1969 p. 44).

However, "antinomies may arise within the internal morality of law itself" because "the various desiderata which go to make up that morality may at times come into opposition with one another." For instance, consistency (principle v) and intelligibility of law (principle iv) are both important objectives of a legal system. However an "economic" trade-off between 
these two goals may well arise and "it may become necessary to pursue a middle course which involves some impairment of both desiderata" (Fuller 1969 p. 45). In this respect Fuller refers to a conversation that he had with a former Minister of Justice of the Poland. She told Fuller how "in the early days of the communist regime an earnest and sustained effort was made to draft the laws so clearly that they would be intelligible to the worker and to the peasant." However an "economic" trade-off emerged. "This kind of clarity could be attained only at the cost of those systematic elements in a legal system that shape its rules into a coherent whole and render them capable of consistent application by the courts" (Fuller 1969 p. 45). This made unavoidable some retreat where both the "marginal utility" of consistency and clarity were taken into account.

If law-making is the enterprise to subject human conduct to the governance of rules this implies that "it may be carried with varying degree of success. This means that the existence of a legal system is a matter of degree."

While in the Coasian view a system of markets cannot be taken for granted because costly resources are involved in the use of the market mechanism, according to Fuller a system of complete rules of law cannot be taken for granted for similar reasons. Moreover, in the Coasian view, the cost of using the market mechanism implies that institutions other than markets are used to coordinate human activities. In a parallel way, Fuller points out that more than one legal system may coexist: EEC, national states regional and provincial governments are well known examples of this circumstance. Furthermore the numerous "public orderings" are necessarily complemented by even more numerous "private orderings."

However, the symmetry between Coase and Fuller becomes particularly clear when we consider the role that the firm plays in both approaches.

In a way similar to the State - the mythical King Rex considered by Fuller - also the employer may find it convenient to have a "legal system in miniature." However when he tries to do so, like King Rex, he runs the same risks of failing to satisfy the eight principles that characterize a legal system.

Moreover, the employer "must not only invest some effort and intelligence in the enterprise, but its very success limits its own freedom of action. If in distributing praise and censure, he habitually disregards his own rule, he may find his system of law disintegrating and without any open revolt, it may cease to produce for him what he thought to obtain from it." (Fuller 1969 p. 47-8)

In other words, in order to reap some benefits from a private ordering, the employer has not only to sustain the related "set up" costs but must also incur the "rigidity costs" of submitting herself to the rules that she has created. The effort may, however, be worthwhile because the "public ordering" may be unable to provide the specific rules that may adequately regulate the principles of conduct that are appropriate to run that particular business.

Thus, Coase and Fuller come to the common conclusion that the internal structure of the firm may be rather important for the success of business activities. Their starting points seem to be rather different. Coase founds his argument on costs that should have been otherwise incurred to run market transactions among separate economic agents. If the costs of running the corresponding market transactions were zero, there would be no explanation for the existence of a costly institution like the firm. By contrast, the ideal starting point of Fuller analysis is the cost of having a complete and perfect public ordering. If the costs of running 
a complete public ordering were nil, there would be no possible explanation for the "set-up" and "rigidity" costs that are spontaneously sustained by many employers that run that particular form of "private ordering" defining the firm.

In other words, in Coase and Fuller, the firm seems to emerge from two opposite processes. In Coase it seems to emerge as a "centralization" of market transactions. In Fuller it seems to emerge as a "decentralization" of the public ordering. However, in many respects, the two processes describe the two faces of the same coin because many of the costs of running market transactions coincide with the costs of running a "pure" public ordering. When firms, unions, arbitrators and other forms of private orderings do not exist, the market transactions of the agents can only be regulated and enforced by the public ordering. In this situation, the cost of defining and enforcing the rights of the agents, their bargaining and their litigation costs and many other costs may be classified either as the costs of using the market mechanism or as the costs of using the public orderings. In some way these costs can be classified under a single heading: they are the costs of using only "public markets"1 or, in other words, markets that are not supported by the numerous "private orderings" like firms that exist in all the modern real life capitalist economies.

For both Coase and Fuller market contracts are necessarily incomplete. "Public markets" are costly and their incompleteness would be a necessary feature of an optimal world where these costs are an endogenous aspect of the economic analysis. In an optimal world "public markets" should only exist until their marginal benefit is greater than the marginal benefit of the private orderings by which they could be substituted. Moreover, even in an optimal world designed by some omniscient central planner, also the mix of private and public orderings could not aspire to perfection and completeness: all institutions are costly and the benefit that they give by regulating human interactions should always be compared to their costs.

\section{3. "Legal equilibria" and private property}

In a stimulating debate with Fuller (1958), H. Hart (1958) "diluted" the Kelsenian² separation between ethics and law $^{3}$ and took an evolutionary approach to the formation of real life legal systems. However, he retained the idea that the validity of law is the central concept of positive law. A primitive society could well develop a system of "primary" rules without the intervention of central authority and some "grundnorm" from which the validity of the other rules could be logically derived. However, such a system will be upset by uncertainty because in many cases the agents will maintain that different rules exist or should be applied in particular cases. It will also be static because, besides custom and tradition, nobody has the power to change the rules even when it may be urgent to do so. Moreover the system will be characterized by numerous contrasts and by an inability to impose sanctions that go beyond a system of private revenge. For this reason any such social arrangements will tend to evolve a system of "secondary" rules that can give some solution to the problems encountered by the system of "primary" rules that we have just considered. A rule of "recognition," establishing the "Kelsenian" validity of the primary rules, is the first attribute that a proper legal system should evolve. In order for the other shortcomings of a system of primary rules to be overcome, rules of change and of adjudication and sanction 
imposing rules must also be included in the system of secondary rules. Thus, a proper legal system is necessarily based on the existence of "second order" jural relations that give to some agents the power to identify clearly, change quickly and enforce efficiently those primary rules that may also emerge in a primitive society.

The institution of "second order" jural relations requires that some agents invest in the ability to verify and enforce ex-post the rights and the corresponding duties among the different individuals. In this way, they can also create the conditions for expectations that are consistent "ex-ante." In other words, independently of the fact that these agents belong to the "private" or the "public" sphere, they give an important contribution to the elimination of the "disequilibrium" between the rights and the duties of the individuals. Or, in other words, the role of the "second order" jural relations can be thought of as that of creating the conditions for the existence of "legal equilibria" among the rights, the duties, the liberties and the exposures of the different individuals.

The importance of the distinction between "first order" and "second order" jural relations and the issues arising from the internal (in)consistency of a legal system can be better understood by referring to the works of Hohfeld (1919) and Commons (1924).

To simplify the argument we shall consider only the transactions between two agents $x$ and y. According to Hohfeld, the "first order" jural relations define some necessary relations between the two agents:

(1) Claim (right) of $x \leftrightarrow$ Duty of $y$

or, in other words, an agent $\mathrm{x}$ has legal claim towards an agent $\mathrm{y}$ that $\mathrm{y}$ does the action $\mathrm{A}$ if and only if $\mathrm{y}$ has with respect to $\mathrm{x}$ the duty to do A.

(2) No right (exposure) of $x \leftrightarrow$ Liberty (no duty) of $y$.

or, in other words, and agent $\mathrm{y}$ has a legal liberty towards and agent $\mathrm{x}$ to do A if and only if $\mathrm{x}$ has no right towards $\mathrm{y}$ to prevent $\mathrm{y}$ from doing $\mathrm{A}$ and is, therefore, exposed to the liberty of $\mathrm{y}$.

Of course, similar relations hold for the claims of $\mathrm{y}$ and the liberties of $\mathrm{x}$ :

(3) Claim (right) of $y \leftrightarrow$ Duty of $x$

(4) No right (exposure) of $y \leftrightarrow$ Liberty (no duty) of $x$

In this simple two-individual-relation the set of actions for which $\mathrm{x}$ has rights do not only define the duties of $y$. They define also the remaining actions for which $y$ has the liberty to act (i. e. the set of actions for which $\mathrm{x}$ has no right to interfere and is exposed to the liberties of y). In other words, in this simple framework, the jural relations entail that the boundary between the rights and the exposures of $\mathrm{x}$ should coincide with the boundary between the duties and the liberties of $y$ and vice versa. Thus, concentrating our attention on relations (1) and (2) we have Table 1 concerning the first order jural relations.

Similar symmetries characterize the second-order jural relations that concern the possibilities of changing the entitlements considered above.

Table 1

First order jural relations 
$\left(1^{\prime}\right)$ Power of $\mathrm{x} \leftrightarrow$ Liability of $\mathrm{y}$

or, in other words, $\mathrm{x}$ has a legal power on an agent $\mathrm{y}$ to bring about a particular legal consequence $\mathrm{C}$ for $\mathrm{y}$ if and only if some voluntary actions by $\mathrm{x}$ would be legally recognized to have this consequence for $\mathrm{y}$.

$\left(2^{\prime}\right)$ Disability of $\mathrm{x} \leftrightarrow$ Immunity of $\mathrm{y}$

or, in other words, an agent $\mathrm{y}$ has a legal immunity with respect to an agent $\mathrm{x}$ from a specific legal consequence $\mathrm{C}$ if and only $\mathrm{x}$ has not the legal power to do any action that according the law would have the consequences $\mathrm{C}$ for $\mathrm{y}$.

Again, similar relations hold for the powers of $\mathrm{y}$ and the immunities of $\mathrm{x}$ :

(3') Power of $\mathrm{y} \leftrightarrow$ Liability of $\mathrm{x}$

$\left(4^{\prime}\right)$ Disability of $\mathrm{y} \leftrightarrow$ Immunity of $\mathrm{x}$

Also the second order jural relations entail a symmetric correlation between the positions of the two agents. Also in this case, the boundary between the powers and the disabilities of $\mathrm{x}$ should coincide with the boundary between the liabilities and the immunities of $\mathrm{y}$ and vice versa. Again, concentrating our attention on relations $\left(1^{\prime}\right)$ and $\left(2^{\prime}\right)$, we obtain Table 2 concerning the second order legal relations.

Both first-order and second-order jural relations have a prominent role in Commons' analysis of transactions and, in particular, in his distinction between authorized and authoritative transactions.

According to Commons minimum description of a transaction involves the two transacting agents, the two agents who are the next best transacting alternatives for each one of the two agents and the working rules according to which the transaction takes places. ${ }^{4}$ The working rules of the transaction include the definition of the rights, the duties, the liberties and the exposures of the agents or, in other words, their entitlements. However, there is no guarantee that the working rules of the transactions satisfy the relations considered above. ${ }^{5}$ If we concentrate our attention on the two agents $\mathrm{x}$ and $\mathrm{y}$ that are involved in the transactions, the two agents may well hold different views on their entitlements. For instance, the rights of the agent $\mathrm{x}$ may not be correlated with the duties of $\mathrm{y}$ and the liberties of $\mathrm{y}$ may not be correlated with the exposures to these liberties of x. In other words, the limit between the rights and the exposures of $x$ may not coincide with the limit between the duties and the liberties of y. An "authorized transaction" occurs when, because of the activity of a fifth agent (the public authorities), the limit between the rights and the exposures of each agent coincides with the duties and the liberties of the other agent.

However, "authorized transactions" cannot be taken for granted. They require "authoritative transactions" and second order jural relations. In other words, a legal system can help to guarantee the correlation among the entitlements of the different agents.

Like for the case of the first order jural relations, also authoritative transactions may occur in a situation of "disequilibrium" where the limit between the powers and the disabilities of

Table 2

Second order legal relations 
one agent do not coincide with the liabilities and the immunities of the other agent. Commons observes how, from the Magna Carta onwards, legal systems have progressed towards the establishment of an increasingly clear correlation between powers and liabilities on the one hand and disabilities and immunities on the other.

The type of transactions, which are considered by standard economic theory, requires a complex equilibrium that involves both "authorized" and "authoritative" transactions. For instance, the boundary between the claims and the exposures of $\mathrm{x}$ must coincide with the boundary between the powers and the disabilities that public officials have to enforce his entitlements with respect to $\mathrm{y}$. In a similar way, the limit between the duties of $\mathrm{y}$ and his liberties must coincide with the limit between the relative liabilities and immunities that y has with respect to public officials. Similar "equilibrium" relations must hold for the entitlements of $\mathrm{y}$ with respect to $\mathrm{x}$.

Concentrating on the entitlements of $\mathrm{x}$ with respect to $\mathrm{y}$ we have Table 3 that describes a situation of "legal equilibrium."

In a legal equilibrium the broken line separating the rights and the exposures of $\mathrm{x}$ coincides with the power and the disabilities that are granted to public officials (p. o.) to enforce her rights. It also coincides with the broken line separating the duties and the liberties of $y$ which in turn coincides with the broken line that defines the boundary between the liabilities and the immunities that y has towards public officials.

However, the broken lines of Table 3 do not need to be necessarily aligned. In reality a situation of legal disequilibrium, such as that considered in Table 4, may well arise.

In Table 4, the broken line, defining the boundary between the rights and exposures of $\mathrm{x}$, does not coincide with that defining the boundary between the duties and the liberties of $y$. In this case the powers of and the liabilities towards public officials fail to correlate the legal entitlements of the two agents. By contrast, a well working legal system, equilibrating the power and liabilities that agents acquire through public officials, tends also to equilibrate their rights and duties or, in other words, tends to achieve the legal equilibrium considered in Table 3.

According to Commons the correlation between the entitlements of $\mathrm{x}$ and $\mathrm{y}$ requires a corresponding correlation of the second jural relations between the two agents and public officials. While Kelsen sees the unity and the consistency of the legal system as a pure matter of Logic and concentrates on the analysis of the validity of rules, Commons points out how the jural relations considered by Hohfeld cannot be taken for granted. They do rather require the costly intervention of public officials who attribute correlative powers and liabilities to the agents (via public officials) and, in this way, equilibrate also their rights and their duties. The limits to the powers and to the liabilities of public officials (or their disabilities to act in

Table 3

Legal equilibrium

\begin{tabular}{|c|c|c|c|c|c|c|}
\hline $\begin{array}{l}\text { Power of } \mathrm{x} \\
\text { via p. o. }\end{array}$ & $\longleftrightarrow$ & Right of $\mathrm{x}$ & $\longleftrightarrow$ & Duty of $y$ & $\longleftrightarrow$ & $\begin{array}{l}\text { Liability of y } \\
\text { via p. o. }\end{array}$ \\
\hline $\begin{array}{l}\text { Disability of } x \\
\text { via p. o. }\end{array}$ & $\longleftrightarrow$ & Exposure of $x$ & $\longleftrightarrow$ & Liberty of y & $\longleftrightarrow$ & $\begin{array}{l}\text { Immunity of y } \\
\text { via p. o. }\end{array}$ \\
\hline
\end{tabular}


Table 4

Legal disequilibrium

\begin{tabular}{|c|c|c|c|}
\hline $\begin{array}{l}\text { Power of } x \\
\text { via p. o. }\end{array}$ & Right of $x$ & $\begin{array}{l}\text { Duty } \\
\text { of } y\end{array}$ & $\begin{array}{l}\text { Liability } \\
\text { of y } \\
\text { via p. o. }\end{array}$ \\
\hline$\overline{\text { Disability }}$ & & $\begin{array}{l}\text { Liberty of } \\
y\end{array}$ & \\
\hline $\begin{array}{l}\text { of } x \\
\text { via } p . o .\end{array}$ & $\begin{array}{l}\overline{\text { Exposure }} \\
\text { of } \mathrm{x}\end{array}$ & & $\begin{array}{l}\text { Immunity } \\
\text { of y } \\
\text { via p. o. }\end{array}$ \\
\hline
\end{tabular}

the interest of $\mathrm{x}$ and the immunities of $\mathrm{y}$ from their intervention) do also equilibrate the exposures and the liberties of the agents. In other words, while both first and second jural relations may well be in disequilibrium, a good legal system tends with the help of public official towards the realization of a complex "legal equilibrium" where the conditions considered above are satisfied.

While Commons does not use the term "legal equilibrium" (or the term legal disequilibrium), perhaps, this term can usefully catch the originality of his contribution and his distance from the Kelsenian tradition of the analysis of the validity of legal rules.

In the Kelsenian tradition the "consistency" of rules is a pure matter of Logic and eventual discrepancies have to be solved by stating which rule is hierarchically superior. For instance, if under some circumstances the rules state simultaneously the right of $\mathrm{x}$ to be assisted and liberty of y to do something else, the matter has to be logically solved by checking which of the two rules has priority. In a way the inconsistency did never arise for scholars who were aware of the logical rules governing the system and could easily state the validity of each single rule.

By contrast, according to Commons the consistency of a legal system is only an ideal goal of such system and some degree of disequilibrium is a permanent characteristic of the working of a legal system. ${ }^{6}$ Moreover, in Commons' view, the elimination of disequilibrium is not a pure matter of Logic which requires a "corner solution" stating the priority of the rights of $\mathrm{x}$ over the liberties of $\mathrm{y}$ or vice versa. The costly elimination of the disequilibrium is a real process that may either involve "corner solutions" or "intermediate solutions" characterized by some dilution of the rights of $\mathrm{x}$ and of the liberties of $\mathrm{y}$.

According to Commons the elimination of legal disequilibrium cannot be carried out only by public officials but, like for Fuller, it must also performed by the many agents that have a similar function in the private sphere.

In particular, firms may be seen as "going concerns" where some working rules are established by private agents who bear the costs of setting up a "private" legal equilibrium which is specifically tailored to certain types of transactions.

If we ignore the transaction costs of "public markets," it is not only difficult to understand the role of "private orderings" like firms. It is even difficult to find good reasons for the existence of private property whose fundamental characteristics can be usefully understood by referring to the jural relations considered by Hohfeld and Commons. 
As Simmonds (1986, p.132) points out "The right of ownership is really a complex bundle of claim-rights, liberties, powers and immunities. An owner of land, for example typically enjoys (inter alia) the claim-right that others not trespass on his land, the liberty to walk on his land, the powers to transfer title to others, and the act of immunity against having his title altered or transferred by the act of another."

Private property defines an exclusive right on the use of some good and the duty of others of noninterfere with it. Thus, the individual acquires a liberty to choose among alternative uses of the good and the others are exposed to these choices.

With private goods, private property allows an optimal decentralization of decisions in the sense that no individual is exposed to the liberty (choices) of other individuals. Each new set of uses that improves the utility of the owner of the private good does necessarily lead to Pareto improvements. This characteristic of a private economy holds independently of exchange. This quality of private property cannot be seen in a world of zero transaction costs where individual take together consumption and exchange decisions. In the traditional setting one misses the main quality of private property that is the possibility of taking decisions without incurring in the cost of transacting with other people.

The cost of transacting may be such that the assignment of private rights may be worthwhile even when the liberty entitled to an individual on her private property involves exposures among which other individuals are not indifferent. With positional, ${ }^{7}$ public and complementary goods the assignment of private property rights cannot "separate" consumption decisions from the transactions with other individuals. An externality can be seen as the impossibility of private property rights to eliminate the interferences among the "liberties" of the different individuals. However, if these interferences involve sufficiently limited losses of welfare, unfettered private property may still be convenient because the costs of organizing the relative transactions may well offset the gains obtained when each individual takes into account the exposures correlated to the exercise of his liberties. ${ }^{8}$

The private property of physical assets is the most elementary way in which an overall legal equilibrium can be broken into simpler subsystems. This quality of private property can only be appreciated in a world of positive transaction costs where the interactions among these subsystems is costly. In world of positive transaction costs the same quality is shared by more complex private orderings or lower-level governance structures like firms, which complement the formal norms of the legal systems. The type of legal equilibrium posited by Hohfeld's classification would be impossible if the many agents, working in these subsystems, would not share the burden of eliminating the legal disequilibrium.

However, public and private orderings should not be seen only as substitutes. They are also within certain limits complementary institutions. Private orderings do often require the possibility of appeal to public orderings. Public orderings can check the "constitutional" validity of the private orderings and the ways in which their working rules have been applied. They can also supply the monopoly of physical coercion that belongs to the public ordering At the same time, the public ordering can benefit from the innovations and the experimentation that occur in the sphere of private orderings where, within certain limits, competition can help the selection of the "fittest" working rules. Because of these complementarities the legal equilibria characterizing public and private ordering will tend to coevolve in some path 
dependent way and the efficiency consequences of a legal norm may often differ in different societies.

\section{The New Property Right approach and the institutions of corporate governance}

In some ways, the New Property Right approach has emphasized one aspect of the Coasian argument that we have just considered.

In a world characterized by zero transaction costs, complete contracts could be written and applied at no cost by public officials. In this situation, even when the investments in human capital are specific to physical capital, its ownership is irrelevant for the safety of these investments. Independently of the private ownership of the means of production, each agent can state in a complete contract the conditions of her participation and in particular the retributions that are due for her investment in human capital. Or, in other words, in this situation, the liberty of the owners of physical capital is limited by a complete contract which protects the "exposures" of the other agents who have invested in human capital and have contracted the right to reap the fruits of their investments. Moreover, when the agents can write a complete contract, the power, which the "owners" of physical capital can exercise by holding up their capital, is limited by the immunity that the other agents have against the expropriation of the benefits of their investment in human capital.

In a world of zero transaction cost, a complete contract cannot only protect the investment in human capital against the hazards due to its specificity to physical capital but can also safeguard it against the hazards due to its specificity to the investments in human capital of other agents. After the contract has been signed, public officials can limit the liberty of each agent to use her human capital in a way that damages the other agents who have also invested in specific human capital. Public officials can also limit the power that the agents have to withdraw their human capital from cooperating with other agents and can in this way give these agents some sort of immunity against the hazards of hold-up.

For these reasons, when market transaction costs are zero (or the cost of using a centralized legal ordering is zero), it is possible to achieve a first best solution. The agents invest in human capital up to the optimal point where the marginal cost of their investments is equal to their marginal cost.

In the New Property Right approach the importance of private property emerges very clearly when third parties cannot verify the efforts or the results obtained by investing in human capital and it is, therefore, impossible to write a complete contract. Under these circumstances each agent is exposed to the threat of noncooperation of the other agents and the first best result cannot be achieved because the public officials cannot impose penalties that eliminate the advantages of this type of behavior. In this situation the private property of physical capital can give some advantages that would not arise in a situation of zero transaction costs (or zero cost verification by the public ordering). Owners are entitled to do with their goods whatever thing is not explicitly forbidden by contracts and their residual liberties can well include actions that expose other agents to the negative consequences of the exercise of these liberties. Moreover, when this is not limited by contractual obligations, 
private property entitles the owners with the right to withdraw the use of physical capital from the other agents also in the case when their human capital investment is specific to this physical capital.

When contracts are incomplete, private property matters for human capital investments and the ownership of physical capital becomes most valuable for those agents who have to make the most relevant and specific investment in human capital. In case of break up of cooperation with the other agents owners can at least count on the access to physical capital. Ownership increases bargaining power with respect to other agents and provides owners with a greater incentive to invest in human capital in comparison to the other individuals.

However there is very little that ownership of physical capital can do to guarantee the cooperation of the other agents. Thus, even the agent who owns the physical capital is exposed to the hold up of the agents who have invested in specific human capital. Moreover, all the other agents are exposed to the risks of hold-up of human and physical capital.

The gap between the "first best solution" obtained in a situation where there are complete contracts and the "second best solution" that is obtained with an efficient allocation of physical capital can, under some circumstances, become very wide. It becomes equal to zero when only one agent has made human capital investments that are specific to physical capital and no agent has to make investments specific to the human capital of the other agents. By contrast, it becomes very large when many agents have to make investments in human capital that are specific to the other agents and to physical capital. In the first case the "efficacy" of the "correct" allocation of private property (measured as a means of narrowing the gap between the "first" and "second" best) is maximum. In the second case the "efficacy" of the "correct" allocation of private property is almost negligible. When private property is the only tool that an economic system can use to face the problem of contractual incompleteness, the underinvestment in human capital can turn out to be unbelievably large.

Thus, the New Property Right approach provides an interesting example in which, because of the impossibility of third party enforcement, private property matters. However, it does not provide much insight in the theory of the firm and to the question "why do firms exist?."

The attribution of private property of physical capital to the people who make the most relevant investment in human capital has little to do with the existence of that complex institution that is the firm. As Bolton and Scharfstein (1998) have observed, only a preBearle\&Means analysis can ignore the very frequent separation of ownership and control. There is often a complete lack of identity between those who have invested in the physical capital of the firm and those who have made the largest human capital investment to run it. Moreover, as Kreps (1990) has pointed out, identifying (or rather confusing) the problem of the existence of the firm with that of the ownership of physical capital would leave us with little or nothing to say for firms that make little use of physical capital. The firm should not be confused with the private property of some means production but should rather be seen in the Coase-Fuller tradition as a "private ordering" that might or might not be related with the ownership of the physical capital that it uses.

The problem with the New Property Right approach is that it considers a dichotic world where third parties can verify some contracts at zero cost and some other contracts at an infinite cost. The markets for physical capital operate at zero transaction costs and their efficiency is not limited by any wealth or credit constraint. By contrast, the contracts for the 
results or the efforts of human capital investments are characterized by a total impossibility of third party verification or, in other words, by infinite transaction costs.

In other words, in the New Property Rights approach the costs of the public ordering are assumed to be either zero or infinite (this is still another way by which the "Swiss cheese" assumption, that is implicit in this theory emerges). This assumption can help to understand the importance of the private property of physical capital in the context of a simple example. However, it obscures the role of the public ordering and implies conditions under which the incentives to invest in the set up and the enforcement of the working rules of private orderings cannot arise. If the cost of third party verification of certain relations is zero or infinite, it cannot be convenient to invest in verification capacities especially when these abilities have to be specific to these relations. By contrast, this convenience can well arise when verification costs are strictly positive but not infinite.

With strictly positive but noninfinite verification costs, public investments in the public ordering (or in the "centralized" legal equilibrium that is often implicitly assumed to exist for free in standard economic theory) may well become convenient. In this way, the degree of contractual incompleteness, which we should expect in "public" markets, can well become an endogenous economic problem. Moreover, with strictly positive but noninfinite verification costs also the private agents can conveniently invest in building up and running "decentralized legal equilibria." In this context, one of the most relevant economic problems becomes the analysis of the relations of complementarity and substitutability of public and private orderings and, in particular, the analysis of the relations between public markets and the institutions of corporate governance.

Williamson (1996, p. 95) has pointed out how classical contract law "applies to the ideal transaction in law and economics in which the identity of the parties is irrelevant." In this case public authorities, making general purpose investments in the enforcement of fairly standardized contracts, can create the conditions for the existence of efficient anonymous "public markets." When specific investments make it relevant the identity of the parties, even relevant investments by public authorities cannot bring about a satisfactory degree of contractual completeness. In this case the initial contract cannot be a good framework to understand the long-standing relations that are likely to characterize the relations among the agents. In this situation, as the New Property Rights approach suggests, the allocation of "private property" of capital may become a relevant way to enhance efficiency. However, the emergence of a "private ordering" can be a much more effective way to deal with this situation.

Arbitration can be interpreted as a rudimentary form of private ordering in which some agents make specific investments in the understanding of the specific relations of other agents and contribute to subject their behavior to the governance of rules that reduce the hazards of contractual incompleteness. In this respect Williamson (1996, p. 97) refers to the following passage by Lon Fuller who pointed out some of the ways in which, unlike courts, arbitrators can help to achieve this result:

"[T]here are open to the arbitrator. . . quick methods of education not open to the courts. An arbitrator will frequently interrupt the examination of witnesses with a request that the parties educate him to the point where he can understand the testimony being received. This education can proceed informally, with frequent interruptions by the arbitrator, and by 
informed persons on either side, when a points need clarification. Sometimes there will be arguments across the table, occasionally even within each of the separate camps. The end result will usually be a clarification that will enable everyone to proceed more intelligently with the case (Fuller, 1963 pp. 11-12).

This passage shows how the creation and use of private orderings can contribute (much more than the allocation of the private property of physical capital) to the solution of the problems arising from contractual incompleteness. When we remove the assumption that third parties cannot make specific investments to monitor and verify particular relations, we can easily see that the specificity of particular relations may easily involve a "second order" specificity. In this situation, some agents may well invest specific human capital in the understanding of the specific relations existing among the agents and contribute to the set up and to the application of better working rules.

Unified corporate governance may be a much more pronounced step in the substitution of a public ordering for a private ordering. The continuity and the specificity of some relations may favor "second order" specific investments that go well beyond those involved by arbitration. While arbitration is an intermediate form that can often revert to forms of litigation at the public courts, the substitution of the public ordering that is operated by corporate governance is much more evident.

Williamson (1996 p. 98) observes that the "implicit contract law of internal organization is that of forbearance. Thus, whereas courts routinely grant standing should there be disputes over prices, the damages to be ascribed to delays, failures to quality and the like, courts will refuse to hear disputes between one internal division and another over identical issues. Access to courts being denied, the parties must resolve their differences internally. Accordingly, hierarchy is its own court of ultimate appeal."

Public Courts, arbitration, internal hierarchy and, in general, the institutions of corporate governance can be thought of as the results of investments that agents make to overcome the problems of contractual incompleteness. They build "legal equilibria" where the agents can share the same expectations about their rights, their duties and, in general, about all the ingredients of the Hohfeldian classifications. Public authorities and public courts have an obvious advantage for general purpose investments in building and verifying general purpose legal equilibria, that have a pronounced "public good" nature and could be applied to most agents in the economy when they transact in some relatively common manner according to well specified initial contracts. Arbitration and other forms of market intermediation may involve a mild level of specific investments that are necessary to run mildly specific transactions. Internal hierarchies have a comparative advantage when specific relations by agents developing specific characteristics make it impossible to run the relations by simply referring to the initial contract. In this case "second order specific investments" in the handling and verification of specific relations may be advantageous. A specific private ordering may successfully replace some functions of the general purpose public ordering that is run by Public Courts and/or some functions of arbitrators and of market intermediaries. Or, in other words, under this situation many "private" institutions, including the Coasian firm, are likely to emerge. 


\section{GM, Fisher Body and "second order specific investments"}

According to Oliver Hart (1995) the integration of Fisher Body and GM is a standard and well-known example of the incentive effects of private property. It shows that the acquisition of the private property of physical capital can be the means to incentivate human capital investments. It clarifies the advantages of vertical integration and the costs of the expansion of the boundaries of the firm. However, we will argue that the Fisher Body-GM story provides a powerful counterexample to the New Property Right approach. It shows that, while the acquisition of the private property of the means of production by the individual making the greatest investment in physical capital may in some cases be irrelevant, the other characteristics of a private ordering may best explain vertical integration and the boundaries of the firm.

Hart (1995, p. 7) observes that "for a long time Fisher Body and GM were separate firms linked by a long-term contract. However, in the 1920s GM's demand for car bodies increased substantially. After Fisher Body refused to revise the formula for determining price, GM bought Fisher out."

Why vertical integration (and not simply a better contract) was the solution to the problems between GM and Fisher Body?

According to Hart (1995, p. 7) one can argue that "GM recognized that, however good a contract it wrote with Fisher Body, situations similar to the one it had just experienced might arise again; that is contingencies might occur that no contract could allow for." Ownership of Fisher Body gave GM extra power by giving it residual control rights over Fisher Body assets. If similar contingencies were to arise again in the future, GM could now even dismiss the managers of Fisher Body if they refused to accede to GM's request.

The interpretation, consistent with the property right approach, relies on the idea that the acquisition of assets by GM increased the incentive to invest of GM managers in figuring out how to reduce costs more than it decreased the incentive to invest by Fisher Body managers. The allocation of ownership was efficient: ownership increased the bargaining power and the incentives of the agents who should make the most relevant human capital investments. According to the New Property Right approach, ownership over assets means power over people and "firm boundaries are chosen to allocate power optimally among the various parties to a transaction." Or, in other words, "power is a scarce resource that should never be wasted" (Hart, 1995, p. 7).

In general, the strong incentives that, according to the New Property Right approach the ownership of physical assets gives to individuals raises the question "why firms, as opposed to individuals, should own any assets" (Holmstrom, Roberts p. 79). ${ }^{9}$ As Bolton and Scharfstein have observed, the GM-Fisher Body example is particularly unfortunate to show the incentive advantage of private ownership. As a result of the take-over a famous GM manager Alfred Sloan acquired the control of the Fisher Body owned by the Fisher family. If we look at this case through the lenses of the famous Berle and Means contribution the main implication of the merger is that "now Fisher Body is run by a manager and agent of owner (Sloan) instead of by the owners themselves (the Fisher brothers)". ${ }^{10}$ One could even speculate that the merger lead to greater inefficiencies due to increased agency costs. One could even maintain that "the merger itself was a manifestation of agency costs, a desire to 
build and empire by a manager who does not bear the full costs of the decision (Bolton and Scharfstein 1998, p. 103).

One could try to defend the New Property Rights interpretation of the GM-Fisher Body case by assuming that Sloan was, indeed, acting as the agent of the GM shareholders who, thanks to the take-over, were protected against the danger of the hold-up and could afford to pay a higher cost for the investment in human capital of their agents. However, especially if one looks at the actual ownership structure at the time of the take-over, this line of defense is very problematic.

The "take-over" occurred in 1926. Since 1919 GM had not only signed the famous vague long term contract but it had also acquired the ownership of the $60 \%$ of the Fisher Body Stock - the other $40 \%$ belonging to the Fisher family. ${ }^{11}$ The "take-over" was hardly necessary to increase the investment in human capital of the agents of GM shareholders for the simple fact that GM had already the control of Fisher Body. Moreover, if transferring "scarce power" via ownership of physical assets from the Fisher family to GM shareholders is considered to be the main motivation for take-over, it is difficult to explain the strong and qualified presence that the Fisher brothers had in GM before and after the "take-over". 12

Klein, Crawford and Alchian (1978) provide some evidence for the "hold up story" that, thanks to their widely quoted article, has been taken as the paradigmatic case by most of the literature including Hart (1995). Their evidence is entirely based on the testimony provided by Alfred P. Sloan in United States v. Du Pont \& Co. By the end of 1919 Du Pont had acquired the $23 \%$ of the GM stock and by 1921 it increased its ownership to about the $36 \%$ of the Corporation (Sloan, 1963 p. 69). At that time Pierre Du Pont was the Chairman of the Board of Directors of the Company - a position that he still held in 1926 at the time of the Fisher Body "take over." One of the charges that the American Government was trying to demonstrate that General Motors vertically integrated in order to get the Fisher Body Corporation buy its glass requirements from Du Pont. In his testimony Alfred S. Sloan (who was going to succeed Pierre Du Pont in 1937 as board chairman and in 1919 was already part of the Board of Directors and a member of the Executive Committee) had a vested interest to point out at those facts that demonstrated the independence of the Fisher Body Corporation. These facts included its capacity to hold up GM in spite of its majority stake in Fisher Body.

Another (and, in my opinion, more convincing) explanation is offered by Alfred Sloan himself in his book My Years with General Motors (Sloan, 1963). ${ }^{13}$ One could summarize his explanation by saying that, with the shift to the production of closed bodies, the different parts of the car had become so highly cospecific to require a different system of governance. "There were operating economies to be gained by coordinating body and chassis assemblies, and with the closed body becoming dominant in the industry, it seemed sensible to bring the body operation entirely under the General Motors Roof. And it was felt desirable also to bring the Fisher brothers into closer relationship with our organization" (Sloan, 1963 p. 184). The importance of a closer relationship with the Fisher brothers was given an even greater emphasis in the 1926 Annual Report of General Motors Corporation. ${ }^{14}$

Thus, the extrapower to be gained with acquisition of the physical capital of Fisher Body could not be an important motivation of the take over. Not only GM already owned the 60\% of the physical capital of Fisher Body but the main purpose of the integration of Fisher Body 
into GM seems to have been a more complete "acquisition" of the human capital of the Fisher brothers. The increase of the cospecificity, due to the advent of closed bodies, implied that high "second order" specific investment in the appropriate private ordering were necessary to guarantee a more efficient cooperation of the Fisher brothers with the other managers who were involved in the construction of the new closed cars. In other words, the purpose of the merger seems to be introduction of a system of private governance where some fair exercise of power could decrease the hold up risks faced by all the agents investing in cospecific human capital.

Indeed, before the acquisition, the development of a private ordering internal to GM had made remarkable progresses giving raise to a decentralization of operating responsibilities and centralized policy formation in the hands of an Executive Committee. According to Sloan, the Executive Committee "which views the corporation as a whole and at the same time is closely familiar with operating problems, has a somewhat judicial function" (Sloan, 1963 p. 458). The need for a central office, having a "judicial function" that favored a smooth coordination among the different divisions, ${ }^{15}$ had emerged very clearly in the early twenties also as a reaction to the conflicts related to the Copper-cooled Engine-a failed innovation that had caused many troubles to Chevrolet cars. ${ }^{16}$

The "private ordering" that Alfred Sloan had created involved the set up, the running and the enforcement of a "private legal equilibrium" under which the different divisions could share common expectations about the boundaries between their rights and the exposure to the liberties of the other divisions (and about the boundaries between their liberties to make decisions and their duties to comply with the decisions of the other divisions).

Before Sloan's reorganization of GM the situation was well different. The Executive Committee was composed of division managers and there were no headquarters acting as intermediary between and coordinator of the different divisions. As a result there was a lot of horse trading among division managers. Each manager was ready to approve other projects on condition that he could get a favorable vote on his own project (Chandler, 1962 p.127, Bolton and Scharfstein 1998, p. 103.). Presumably, disputes like the one between GM and Fisher Body considered by Hart could also well arise among the GM divisions preexisting the merger and they would have been inefficiently solved by the some type of horse trading among managers. Perhaps, the acquisition of GM in this situation would have resulted in an unbearable further growth of costs due to the wasteful rent-seeking activities of the managers

However, before the acquisition of Fisher Body, a new private ordering characterized by different working rules had already emerged at GM. Under the new working rules the division managers would now bargain being well aware that there was a third party in the bargain: the corporate headquarters who had ultimate control over the company resources and were hierarchically superior to the division managers. Under the new working rules, in Sloan's mind "a merger with Fisher Body was called for essentially to bring Fisher Body under the umbrella of the newly created administrative structure and thus take full advantage of the coordination benefits of General Motors' general office" (Bolton and Scharfstein 1998, p. 105). The move became almost compulsory with the dominance of the production of closed cars.

Thus, in the Fisher Body-GM case, the choice was not so much among different 
allocations of the private property of physical capital but mainly between the use of "public markets" and the use of a (new) private ordering. The top managers made some "second order specific investments" 17 in human capital specific to the specific relations that were at stake. The investments did not only include the set up costs of devising the working rules of a new private ordering but also the specific investments necessary to monitor and verify the relations among division managers. These specific investments were unlikely to be done by courts and other public officials supervising "public markets" or even by arbitrators. The absence of these "second order specific investments" was, perhaps, in many cases at the origin of the situation of pronounced contractual incompleteness that characterized the relations between GM and Fisher Body when they were independent companies. In terms of the Commons' terminology the switch from public markets to the new private ordering implied a form of corporate governance that had internalized not only some the "authorized" transactions that existed between the two companies but also some of the "authoritative" transactions between them and public officials. The "legal equilibrium" that, before the merger, failed to be achieved by the working of public officials and/or arbitrators could now be achieved thanks to the "authoritative transactions" between headquarters and division managers.

With the acquisition of Fisher Body the headquarters of GM became the "ultimate court of appeal" in the disputes between the managers of Fisher Body division and the other managers of the GM plants. Moreover, in a way analogous to that considered by H.L.A. Hart (1961), the headquarters set up systems of secondary rules that improved on the primary rules that the agents could work out without their intervention. The continuity and specificity of the relations made it difficult for public authorities ${ }^{18}$ to device appropriate secondary rules. Specific secondary rules were required to run specific and continuously evolving relations. A "private judiciary" with the specific knowledge of these relations was required for their application. Or, in other words, the elaborate institutions of corporate governance elaborated by Alfred Sloan, the Fuller's "King Rex" of GM, emerged as the best way to improve on the high level of contractual incompleteness that characterized "public markets."

\section{Conclusion}

Whereas the acquisition of Fisher Body by GM replaced the working of the public markets with a private ordering, the further separation of ownership and control that it entailed implied the necessity of new complementary roles for the public ordering. While the disputes between GM and the former Fisher Body plants could be left to the private ordering created by Alfred Sloan, it became necessary to have public authorities increasing the transparency of the stock exchange and courts able to assess whether managers had carried out their fiduciary duties. In turn these developments created new opportunities for the private ordering existing in the economy. The complementarities and the substitution among the private and public ordering of the economy developed along a path whose analysis is well beyond the scope of this paper. However, it is worthwhile to conclude with three observations.

In the first place the complementarity and substitution relations between the public and 
private sphere of the economy imply that many paths of institutional development are possible and we should not be surprised if different countries have developed different models of corporate governance. ${ }^{19}$ The rent seeking activities within both private and public orderings may imply that different agents in different countries have different safeguards for their assets. These safeguards may induce different levels of investments that may, in turn, create new demands of more effective safeguards. Self-reinforcing organizational equilibria can, therefore characterize the public and private ordering of the different countries and explain the diversity of their history.

Secondly, while the paper has focused on the relations between "formal" systems of private and public orderings, the study of these systems cannot be abstracted from the informal rules, the customs and the ethical codes that have evolved in different countries. ${ }^{20}$

Finally, the desirability of a public policy cannot be judged independently of the particular history of the public and private orderings of a particular country. Perhaps, the only general recommendation, which emerges from our analysis, is that one should never forget that markets rely very much also on the public ordering of the economy and that they cannot be created by simply destroying pre-existing forms of State intervention. ${ }^{21}$

\section{Notes}

1. The term "public markets" was somehow suggested by the concluding lines of the famous Alchian and Demsetz (1972, p. 795) who observed:

"In contrast to markets and cities, which can be viewed as publicly or non owned market places, the firm can be considered a privately owned market; if so, we could consider the firm and the ordinary market as competing types of markets, competition between private proprietary markets and public or communal markets. Could it be that the market suffers from defects of communal property rights in organizing and influencing uses of valuable resources?".

2. Kelsen (1992) considered the validity of the law or its consistency as the proper object of legal studies and argued that the validity of legal rules should be distinguished from their justice and efficacy. If some final "grundnorm" was transcendentally given the unity, the consistency and the completeness of the legal ordering could be established by checking the consistency of the rules with the hierarchical superior rules.

3. For other authors, like Finnis (1980), even a partial separation is impossible. At least the final "grundnorms" must be based on some ethical principles.

4. In other words Commons' notion of transaction costs does not only include the traditional enforcement costs which characterize the relation with the counterpart. It includes also the cost of the public institutions and the competition costs to be sustained by the agents when they seek to exclude their competitors from the market. On this point see Nicita $(1999,2000)$ who introduces the notion of cross competition that arises when both the assumptions of zero enforcement and competition costs are removed.

5. Commons (1924) observes that Hohfeld transactions can also be interpreted as ethical relations existing among the agents and may also be supported by traditional believes. 
However, Commons (1924 p. 85) observes that "There is, however, a difficulty with these ethical mandates. They are mental processes and therefore as divergent as the wishes and the fears of individuals. Hence, when they emerge into action they are individualistic and anarchistic. They are unrestrained in action by an actual earthly authority to whom each party yields obedience." The lack of subjective correlation may express itself in the fact that one agent sees the boundary of his rights different from the related boundary of the duty of the other agent. For this reason, according to Commons (1924, p. 86), "It seems that the only procedure that will collerate the wishes and fears of each and prevent anarchy is to resort to a third person of an earthly quality whom each consents to obey, or each is compelled to obey."

6. Like most economic relations, legal relations become "ex-post" simple accounting identities. "Ex post," if $\mathrm{x}$ was exercising some rights, y was necessarily observing some duties. However, the existence of these "ex-post" accounting identities does not imply that there was "ex-ante" equilibrium between the expectations of $\mathrm{x}$ of her rights and the expectations of y of his duties. In other words, "ex-ante" disequilibrium is consistent with the "ex-post" identity between rights and duties (or between liberties and exposures etc.).

7. Positional goods can be considered as a case polar to public goods and involves the joint consumption of a positive and negative quantity of the same good. Power and status are good examples of positional goods. On this point see Pagano (1999).

8. In the case of work, if people care about the allocation of their own labor, private property rights cannot separate the welfare of individuals after exchange. One cannot sell her labor power to another person and then walk away. In orthodox economic theory the exchange of labor power becomes equal to the exchange of any other private good only because leisure (and not the different types of work) are included in the utility function of the individuals. On this point see Pagano (1985).

9. According to Holmstrom and Roberts (1998) at the present the property rights models are so stylized that they cannot answer this questions. Perhaps, as a consequence, they are even less suitable to consider the "State versus Private Ownership" problem examined by Shleifer (1998). An interesting step in this direction is offered by Iwai (1999).

10. See Bolton and Scharfstein (1998, p.103) who point out that in 1939 Sloan had 0.82 of GM stock and was unlikely to have more than that amount at the time of the acquisition of Fisher Body.

11. This point is completely ignored by Hart (1995). However, the incompleteness of a contract may well be justified by the fact that it was coupled with the ownership of the $60 \%$ of the stock!

12. Fred J. Fisher was already a member of the powerful GM Executive Committee in 1922 and in 1924 he was also made a member of the Executive Committee. In that year Charles T. and Lawrence P. Fisher were made members of the Executive Committee and in 1925 (one year before the "take-over") the latter became also the President of Cadillac. At the time of the "take-over" three other Fisher brothers stayed at Fisher Body Corporation. One of them William A. Fisher was its President (see Sloan 1963, pp. 184-5). In the last page of his book Sloan (1963, p. 467) includes 
Fisher among "the remaining older member of management, who have been and continue to be large individual shareholders."

13. It is very strange that, in spite of the extensive literature on the GM-Fisher Body case, there is no reference in the literature to what Sloan says about it in his very interesting book.

14. In the section referring to what has just become the Fisher Body Division of GM. "Of even greater importance, - it is claimed - is the bringing into General Motors operating organization in closer relationship, the Fisher brothers, through whose constructive ability, foresight and energy the institution bearing their name has been built up to the dominating position it now holds" (Dupont et al., 1927, p. 10).

15. The importance of coordination is not adequately considered by the literature that has concentrated its attention on situations where no (sometimes specific) resources are expended in making demand consistent with supply among or within firms. On the relevance of "disequilibrium transaction costs" see Pagano (1992). For an early view of managers as references see Aoki (1984).

16. See Chapter 5 of Sloan (1963). "The problem was-according to Sloan (1963, p. 94) - one of conflict between the research organization and the producing divisions, and of a parallel conflict between the top management of the corporation and divisional management."

17. This role of "second order specific investments" is consistent with the definition of the firm as a nexus of specific investments advanced by Zingales (1998, p. 499).

18. However, with the help of standardization and other forms of agreements among agents it is possible to decrease the "specificity" of the investments (Pagano, 1991 and Battistini, 1998).

19. On the divergence of corporate governance models see Pagano $(1993,1999)$, Pagano, Rowthorn (1996), Barca, Iwai, Pagano, Trento (1999) and Screpanti (1998). The particularity of law and its context dependent character are considered in Mattei and Cafaggi (1998).

20. As Hodgson (1988, p. 160) points out "The vision of a 'pure' market or capitalist system which has driven out all vestiges of habit and tradition is both theoretically implausible and unrealizable in practice." For this reason the stream of institutional economics related to Commons' work should be integrated with that deriving from Veblen. On the different streams of institutional economics see Hodgson (1998).

21. Unfortunately, the opposite philosophy prevailed in the mass privatization process that was advocated for Russia and other ex-socialist economies. For a criticism of this economic ideology see Stiglitz (1999) and Black, Kraakman, Tarassava (1999).

\section{Acknowledgments}

This paper is part of the P. I. N. financed by M.U.R.S.T. on "Incomplete Contracts and the Analysis of the Institutions" and it has been presented at the 16th Annual Conference of EALE (European Association of Law and Economics) held in Castellanza (Italy) 16-18 1999. I thank the participants to the sessions and, in particular, the discussant of the paper 
Per-Olof Bjuggren for their stimulating suggestions. I thank also Marcello de Cecco, Maurizio Franzini Antonio Nicita and Ernesto Screpanti for their useful comments. Finally, I thank three anonymous referees of the Journal for their very useful comments.

\section{References}

Alchian and Demsetz (1972). Production, Information Costs and Economic Organization. American Economic Review, 62 pp. 777-95.

Aoki M. (1984). The co-operative game theory of the firm. Oxford: Clarendon Press.

Barca F., Iwai K., Pagano U., Trento S. (1999). The Divergence of the Italian and Japanese Corporate Governance Models: The Role of the Institutional Shocks. Economic Systems Vol. 23 pp. 35-59.

Battistini A. (1988). Competitive Imitation, Asset Specificity and Efficiency. Quaderni del Dipartimento di Economia Politica N, 227, Università di Siena.

Berle A.A., Means G.C. (1997). The Modern Corporation \& Private Property. Transaction Publishers, New Brunswick, US.

Black B., Kraakman R., Tarassava A. (1999). Russian Privatization and Corporate Governance. What Went Wrong? Mimeo, Stanford.

Bolton P., Scharfstein D.S. (1998). Corporate Finance, the Theory of the Firm, and Organisations. The Journal of Economic Perspectives V. 12 pp. 95 -115.

Chandler A. (1962). Strategy and Structure. MIT Press, Cambridge, MA.

Coase R.H. (1937). “The Nature of the Firm” Economica pp. 386-405. Reprinted in R. H. Coase (1988) The Firm, the Market and the Law. University of Chicago Press, Chicago pp.-57.

Coase R.H. (1960). "The Problem of Social Costs” Journal of Law and Economics, 3 pp. 1-44. Reprinted in R. H. Coase (1988) The Firm, the Market and the Law. University of Chicago Press, Chicago pp. 95-157.

Coase R.H. (1988). The Firm, the Market and the Law. University of Chicago Press, Chicago.

Commons J. R. (1924) Legal Foundations of Capitalism. Augustus M. Kelley, Publishers, Clifton [reprinted, 1974].

Dupont P.S., et al. (1927) Eighteenth Annual Report of General Motors Corporation. Year Ended December 31 1926. General Motors Corporation, New York and Detroit.

Finnis J. (1980). Natural Law and Natural Rights. Clarendon Press, Oxford.

Fuller L.L. (1958). Positivism and Fidelity to Law - A Reply to Professor Hart. Harvard Law Review V. 71. Reprinted in Feinberg J., Gross H. (1991) Philosophy of Law. Wadsworth Publishing Company, Belmont, California.

Fuller L.L. (1963). Collective Bargaining and the Arbitrator. Wisconsin Law Review Pp. 3-46.

Fuller L.L. (1969). The Morality of Law. (Revised Edition). Yale University Press, New Haven and London.

Hart H.L. (1958). Positivism and the Separation of Law and Morals. Harvard Law Review V. 71. Reprinted in Feinberg J., Gross H. (1991) Philosophy of Law. Wadsworth Publishing Company, Belmont, California. pp. $48-81$.

Hart H.L. (1961). The concept of Law Clarendon, Oxford.

Hart O. (1995). Firms, Contracts and Financial Structure. Oxford University Press, Oxford.

Hobbes T. (1973). Leviathan. First published in 1651. Dent, London and Melbourne.

Hodgson G.M. (1988). Economics and Institutions. Polity Press, Oxford.

Hodgson G.M. (1998) The Approach of Institutional Economics. Journal of Economic Literature. Vol. XXXVI pp. $166-192$.

Hohfeld W.N. (1919). Fundamental Legal Conceptions. Yale University Press, New Haven and London.

Holmstrom B., Roberts J. (1998). The Boundaries of the Firm Revisited. The Journal of Economic Perspectives V. 12 pp. 73-95.

Iwai K. (1999). Persons, Things and Corporations: The Corporate Personality Controversy and Comparative Corporate Governance. American Journal of Comparative Law, vol. 47 pp. 583 -632. 
Kelsen H. (1992). Introduction to the problems of legal theory. A Translation of the First Edition of the Reine Rechtlehere. Clarendon Press, Oxford.

Klein B., Crawford R., Alchian A. (1978). Vertical Integration, Appropriable Rents, and the Competitive Contracting Process. Journal of Law and Economics. XXI (2), pp. 297-236.

Kreps D.M. (1990). Corporate Culture and Economic Theory. In Alt J. E. e Shepsle K. A. Perspective on Positive Political Economy. Cambridge University Press, Cambridge.

Mattei U, Cafaggi F. (1998). Comparative Law and Economics. In Peter Newman (ed.) The New Palgrave Dictionary of Economics and the Law. Macmillan, London.

Nicita A. (1999). Endogenous Outside Options, Incomplete Contracts and the Nature of the Firm. Quaderni del Dipartimento di Economia Politica N, 250, Università di Siena.

Nicita A. (2000). The Firm as an Evolutionary Enforcement Device. Forthcoming in Nicita A, Pagano U eds. The Evolution of Economic Diversity, Routledge, London.

Pagano U. (1985). Work and Welfare in Economic Theory. Basil Blackwell, Oxford.

Pagano U. (1991). Property Rights, Asset Specificity, and the Division of Labour under Alternative Capitalist Relations. Cambridge Journal of Economics. Vol. 15 No 3. Reprinted in G. Hodgson (1993) The Economics of Institutions. Edward Elgar, Cheltenham.

Pagano U. (1992). Authority, Co-ordination and Disequilibrium: an Explanation of the Co-existence of Markets and Firms. Economic Dynamics and Structural Change Vol. 3, No. 1. pp 53-77. Reprinted in G. M. Hodgson; 1993 The Economics of Institutions Edward Elgar, Cheltenham.

Pagano U. (1993). Organizational Equilibria and Institutional Stability. In Bowles S., Gintis H., Gustafson B. eds. Markets and Democracy (pp. 86-115). Cambridge University Press, Cambridge.

Pagano U., Rowthorn R. (1996). The Competitive Selection of Democratic Firms in a World of Self-Sustaining Institutions in Pagano U, Rowthorn R eds. Democracy and Efficiency in the Economic Enterprise Routledge, London p, 116-145.

Pagano U. (1999). Is Power an Economic Good? Notes on Social Scarcity and the Economics of Positional Goods. In Bowles S., Franzini M., Pagano U. (1999) The Politics and the Economics of Power. Routledge, London pp. 63-85.

Pagano U. (2000). The Origin of Organizational Species. Forthcoming in Nicita A, Pagano U, eds. The Evolution of Economic Diversity, Routledge, London.

Posner R.A. (1981). The Concept of Corrective Justice in Recent Theories of Tort Law. Journal of Legal Studies Vol. 10 n. 1.

Posner R.A. (1983). The Economics of Justice. Harvard University Press, Cambridge Ma.

Robertson D.H. (1928). The Control of Industry. Nisbet \& Co, London.

Screpanti E. (1998). The Fundamental Institutions of Capitalism. Department of Political Economy. University of Siena.

Shleifer A. (1998). State versus Private Ownership. The Journal of Economic Perspectives V. 12 pp. 133-151.

Simmonds N.E. (1986) Central Issues in Jurisprudence. Justice, Law and Rights. Sweet \& Maxwell, London.

Sloan A.P. (1963). My Years with General Motors. Pan Books, London.

Stiglitz J. (1999). Whither Reform? Ten Years of Transition. Annual Bank Conference on Development Economics World Bank Washington DC.

Williamson O.E. (1985). The Economic Institutions of Capitalism. The Free Press, New York.

Williamson O.E. (1996). The Mechanisms of Governance. Oxford University Press, Oxford.

Williamson O.E. (1994) Evaluating Coase. The Journal of Economic Perspectives V. 8 pp. 201-203.

Zingales L. (1988). Corporate Governance. In Peter Newman (ed.) The New Palgrave Dictionary of Economics and the Law. Macmillan, London. 